\title{
Physiotherapy and Rehabilitation Interventions in the Conservative Treatment of Chondrocalcinosis: a Case Report
}

\author{
Bihter Akınoğlu \\ Yıldırım Beyazıt University Faculty of Health Sciences, Dept. of Physiotherapy and Rehabilitation Ankara, Turkey
}

\begin{abstract}
Chondrocalcinosis is defined as the accumulation of crystals of calcium pyrophosphate in the hyaline cartilage and fibrous tissue. A 24 years old tennis player referred to our clinic with chondrocalcinosis diagnosis, for conservative treatment. On admission, she had pain and difficulty in walking, stair climbing and sitting up, as well as weakness in front thigh muscles. High voltage galvanic stimulation, isokinetic strength training and home exercises were applied two days a week for six weeks. Following the treatment, there were significant improvements in her daily life activities and quadriceps muscle strength.
\end{abstract}

Keywords: Chondrocalcinosis, isokinetic strength training, physiotherapy

Available at: http://journalofsportsmedicine.org and http://dx.doi.org/10.5152/tjsm.2017.077

Cite this article as: Akinoglu $B$. Physiotherapy and rehabilitation interventions in the conservative treatment of chondrocalcinosis: A case report. Turk J Sports Med. 2017;52:111-5.

\section{Kondrokalsinozis Tedavisinde Fizyoterapi ve Rehabilitasyon Uygulamaları: Olgu Sunumu}

Öz

Konrokalsinozis fibröz ve hyalin kıkırdak dokuda kalsiyum birikimi olarak tanımlanır. Merdiven çıkma, yürüme ve oturduğu yerden kalkma güçlüğünün yanı sıra ön uyluk kaslarında zayıflık yakınmaları ile kliniğimize yönlendirilen 24 yaşındaki kadın tenisçiye altı hafta boyunca haftada iki kez olmak üzere, yüksek voltaj galvanik stimülasyon, izokinetik kuvvetlendirme egzersizleri ve ev egzersiz programı uygulandı. Günlük yaşam aktiviteleri ve kuadriseps kas kuvvetinde belirgin iyileşme gözlendi.

Anahtar Sözcükler: Kondrokalsinozis, izokinetik kuvvetlendirme çalışmaları, fizyoterapi

Geliş Tarihi / Date Received: 05.07.2017. Kabul Tarihi / Date Accepted: 26.08.2017. Yayın Tarihi / Published Online: 07.09.2017. Yazışma Adresi / Corresponding Author: Bihter Akınoğlu, Yıldırım Beyazıt Üniversitesi Sağlık Bilimleri Fakültesi, Fizyoterapi ve Rehabilitasyon Anabilim Dalı, Ankara, Turkey. Email: rgkardelen@yahoo.com

C2017 Türkiye Spor Hekimleri Derneği. Tüm hakları saklıdır. 


\section{GíRIS}

Kondrokalsinozis fibröz ve hyalin kıkırdak dokuda kalsiyum birikimi olarak tanımlanır. Kondrokalsinozisin üç klinik formu vardır. Birincisi hiperparatiroidizm, hemokromatozis, hipotiroidizm ve Wilson hastalığı gibi antitelere eşlik eden formu; ikincisi familyal form ve sonuncusu da sporadik formdur. ICD (International Classification of Diseases) sinıflamasina göre kondrokalsinozis kristal artropatileri ve kristal kökenli artrit grubu içerisinde yer alır $(1,2)$. Literatürde kondrokalsinozisin farmakolojik tedavileri ile ilgili çeşitli çalışmalar olmasına karşın; nonfarmakolojik tedavilerden biri olan fizyoterapi ve rehabilitasyon uygulamalarına yönelik çalışmalara rastlanmamıştır. Cerrahi endikasyonun olmadığı artrit durumlarında fizyoterapi-rehabilitasyon uygulamalarının ağrı düzeylerini azaltıp, yaşam kalitesini arttırabileceği bilinmektedir (3). Kondrokalsinozis tanısıyla kliniğe yönlendirilen ve yüksek voltaj galvanik stimülasyon (HVGS), izokinetik kas kuvvetlendirme egzersizleri ve ev egzersiz programı uygulanan bir olgu sunulmaktadır.

\section{OLGU SUNUMU}

Yirmi dört yaşında kadın tenisçi bir yıldır süren genel yorgunluk hali ve son altı aydır sağ/dominant bacakta daha fazla olmak üzere; her iki bacakta ağrı, merdiven çlkma, yürüme ve oturduğu yerden kalkmada zorluk yakınması ile kliniğe yönlendirilmişti. Hastanın yakınmaları, özellikle akşam saatlerinde artıyor ve istirahatle azalmıyordu. Alt ekstremitelerde sağ uyluk önünde daha fazla olmak üzere elektrik çarpması gibi ağrıdan yakınıyordu. Son iki yıldır tenis oynayamadığını belirten hastanın belirgin travma öyküsü yoktu.
Olgunun elektrik çarpması șeklindeki yakınmalarının son altı ayda artması nedeniyle nöroloji kliniğinde EMG (elektromyografi) yapıldığı ve tüm bulgularının normal olduğu öğrenildi. Bunun üzerine önce ortopedi ve travmatoloji, daha sonra romatoloji kliniğine başvuran hastada tetkiklerin yapıldı̆̆ı ve kondrokalsinozis tanısı konularak kolşisin ve indometazin tedavisine başlandığı öğrenildi. Bu tedavilerden sonra, ağrısının geçmediğini ve günlük yaşam aktivitelerinde zorluk çektiğini bildiren hasta kliniğimize yönlendirilmiştir.

Olgunun değerlendirilmesinde tedavi öncesi ve tedavi sonrasında kuadriseps/ hamstring kaslarında izokinetik kas kuvvet ölçümü yapıldı. Günlük yaşam aktivitelerini ve fonksiyonel bağımsızlık düzeyini değerlendirmek için Lysholm diz skalası ve IKDC 2000 sübjektif diz değerlendirme formu ve Tegner aktivite skalası kullanıldı. Aynı zamanda olgunun sağlıkla ilgili yaşam kalitesini değerlendirmek için Nottingham Sağlık Profili (NHP) kullanıldı.

Uyluk kaslarının kuvvetlendirilmesi amacıyla izokinetik kas kuvvet çalışmaları ve elektroterapi uygulaması planlandı. İzokinetik kuvvetlendirme eğitimi öncesinde genel ısınma egzersizleri ve Isomed 2000 (D \& R Ferstl GmbH, Hemau, Germany) cihazı ile $60^{\circ} / \mathrm{s}$ 'de beş tekrarlık ısınmanın ardından, $60^{\circ} / \mathrm{s}$ hızda üç set 10 tekrar ve $180^{\circ}$ /s hızda üç set 15 tekrarlık konsantrik/ konsantrik kas kuvvetlendirme protokolü uygulandı. Aynı zamanda vastus lateralis ve vastus medialis kasına aynı anda kokontraksiyon oluşturacak şekilde her iki dize dört kanalla yüksek voltaj galvanik stimülasyon (HVGS) uygulandı (Şekil 1). 


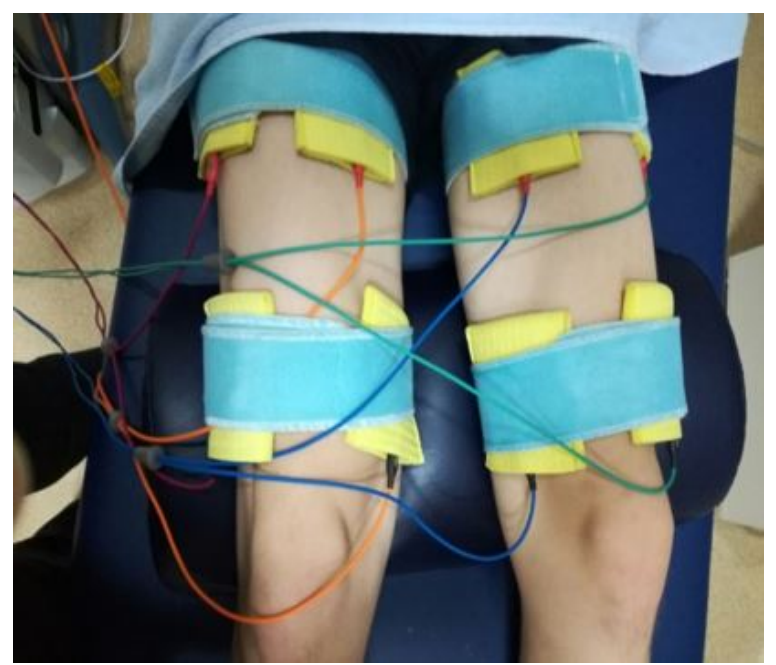

Şekil 1. Kuadriseps femoris kasına HVGS uygulaması

$\mathrm{Bu}$ tedavi programı haftada iki kez olmak üzere toplam altı hafta boyunca tekrarlandı. $\mathrm{Bu}$ süre boyunca ev egzersizi olarak da 'core' endürans egzersizleri günde iki defa, her gün yapılmak üzere verildi ve olgunun egzersizleri yaptığını kontrol etmek amaçlı egzersiz takip çizelgesi verilerek seans öncesinde de egzersizleri doğru yapıp yapmadığı kontrol edildi.

Olgunun tedavi öncesi ve altı haftalık tedavi sonrasındaki değerlendirme sonuçları Şekil 2 'de verilmektedir. Tedavi öncesine göre Lysholm diz skalası puanı, IKDC 2000 sübjektif diz değerlendirme skoru, Tegner aktivite skalası puanı ve Nottingham Sağlık Profili (NHP) değerlendirmesine göre sağlıkla ilgili yaşam kalitesinin arttığı gözlendi. Aynı zamanda tedavi öncesine göre tedavi sonrasında kas kuvvetinde artış kaydedilirken, kuadriseps ve hamstring kaslarının kuvvet oranlarının da norm değerlerine yaklaştığı belirlendi (Tablo 1). Tedavi öncesinde var olan merdiven çıkma, yürüme ve oturduğu yerden kalkma güçlüğü yakınmalarının geçtiği öğrenildi. Bunun üzerine romatoloji uzmanı hekime tekrar yönlendirilen hastanın tetkiklerinin yenilendiği, daha önce başlanmış olan kolşisin ve indometazin tedavisinin kesilmesine karar verildiği öğrenildi.

\section{TARTIŞMA}

Eklem yapılarında kristal depolanmasıyla karakterize, artrit klinik tablosuyla seyreden bir grup hastalıktan biri olan kondrokalsinozis (artiküler kartilaj kalsifikasyonu) genellikle yaşlı bireylerde görülürken (4-7), bu olgu 24 yaşında aktif bireydi. Kondrokalsinozis genellikle sinovyal sıvıya kristal dökülmesiyle oluşan enfla-masyon sonucunda bir gün ile dört hafta arasında kendini sınırlayan psödogut atakları ile seyretmekle birlikte, bu olguda sağ dizde daha fazla olmak üzere altı aydır süren ağrı ve güçsüzlük ön plandaydı ve ataklar şeklinde ortaya çıkan yakınmaları yoktu $(5,6)$. Artritte farmakolojik tedavi seçeneklerinin yanı sıra non-farmakolojik tedavi seçenekleri de uygulanabilir. Bu seçeneklerden biri olan olan fizyoterapi uygulamaları genel olarak eklem hareket açıklığı egzersizleri, kuvvetlendirme egzersizleri, denge, propriosepsiyon ve aerobik egzersizleri içermektedir (8). Kuvvetlendirme eğitiminde kullanılan egzersizler izometrik, izotonik ve izokinetik egzersizlerdir. Tüm eklem hareket açıklığı boyunca kasta maksimum dirençte kasılma sağlayan izokinetik egzersizler kas kuvvetini en iyi arttıran egzersizlerdir (9). Bu bilgilere paralel olarak, bu olguda uygulanan izokinetik kuvvetlendirme programı sonucunda hastanın kas kuvvetlerinde belirgin bir artış gözlendi. 


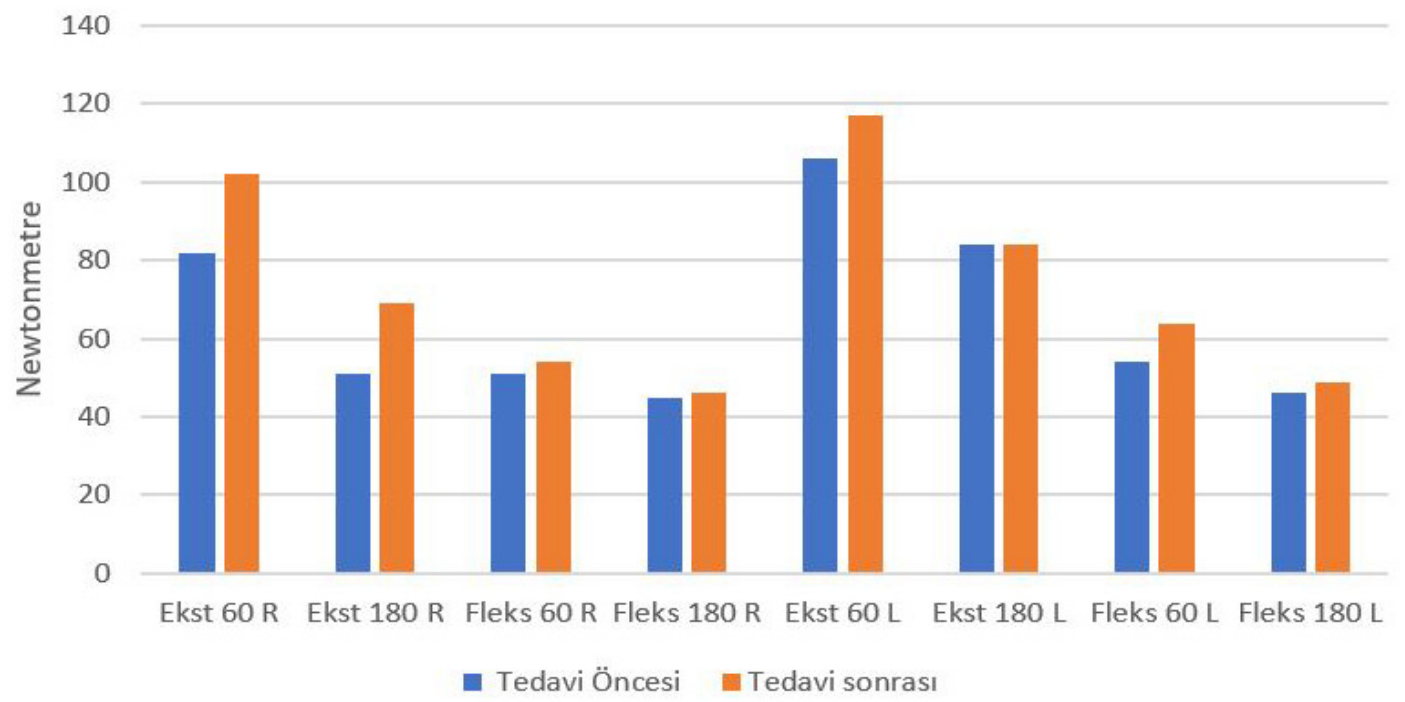

Şekil 2. Tedavi öncesi ve tedavi sonrası uyluk kas kuvvetlerinin izokinetik değerlendirme sonuçları. Ekst: ekstansiyon, Fleks: fleksiyon, R: sağ, L: sol

Tablo 1. Tedavi öncesi ve altı haftalık tedavi sonrası değerlendirme sonuçları

\begin{tabular}{llcc}
\hline & & Tedavi öncesi & Tedavi sonrası \\
\hline Lysholm diz skorlama skalası & 65 & 94 \\
\hline IKDC $\mathbf{2 0 0 0}$ & & 34.5 & 66.7 \\
Tegner aktivite skalası & 1 & 4 \\
\hline $\begin{array}{l}\text { Nottingham sağlık profili } \\
\text { Sağ taraf fleksiyon/ekstansiyon } 60 \mathrm{~s}^{-1}\end{array}$ & 185 & 52 \\
\hline $\begin{array}{l}\text { Diz eklemi izo- } \\
\text { kuvvet oranları }\end{array}$ & Sağ taraf fleksiyon/ekstansiyon $180 \mathrm{~s}^{-1}$ & 87.8 & 53.1 \\
\hline
\end{tabular}

IKDC 2000: Uluslarası Diz Dokümantasyon Komitesi sübjektif diz değerlendirme formu

Artritli hastaların tedavisinde aynı zamanda elektroterapi de kas kuvvetlendirme amaçlı kullanılmaktadır (10). Özellikle kuadriseps kasına uygulanan yüksek voltaj galvanik stimülayon (HVGS), artritli hastalarda hem ağrıda azalmaya, hem de kuadriseps kasında büyük oranda kas kuvvet artışına neden olmaktadır $(11,12)$. Bu olguda HVGS uygulaması bilateral olarak kullanıldı ve osteoartrit ve romatoid artrit tedavisinde yaygin olarak kullanılan fizyoterapi uygulamalarının bir artrit türevi olan kondrokalsiniziste de kullanılabileceği düşünüldü. 
Literatürdeki çalışmalara bakıldığında, kalça kas kuvvetindeki azalma ile birlikte meydana gelen 'core' kaslarındaki instabilite sonucunda diz ekleminin sıklıkla yaralanan bir eklem olduğu sonucuna varılmıştır (13-15). Bu nedenle diz eklemini ilgilendiren tüm hastalıklarda 'core' kaslarını kuvvetlendirmeye yönelik egzersiz programları tedavi programı içerisinde yer almalıdır. Bu olguda da uygulanan fizyoterapi ve rehabilitasyon uygulamalarının bireyin günlük yaşam aktivitelerini daha rahat biçimde yapmasına ve ağrı düzeyinin azaltılmasına yardımcı olduğu belirlendi.

Literatürde bu olguyla benzerlik gösteren ve kondrokalsinozis tedavisinde uygulanması gereken ya da uygulanan fizyoterapi yöntemlerini karşılaştıran çalışmalara rastlanmamıștır. $\mathrm{Bu}$ olguda elde edilen sonuçlar kondrokalsinozisli bireylerin, kronik dönemde oluşan kuvvetsizlik ve ağrı problemlerine yönelik uygulanacak rehabilitasyon yaklaşımlarını olumlu yönde desteklemektedir.

\section{SONUÇ}

Kondrokalsinoziste farmakolojik tedaviden yeterince yarar görülmemesi durumunda, kas kuvvetsizliği ve ağrı yakınmalarının giderilmesi için elektroterapi ve izokinetik kas kuvvetlendirme eğitimi ile birlikte "core" egzersizlerini içeren fizyoterapi ve rehabilitasyon yaklaşımlarının tedaviye eklenmesinden hasta yarar görebilmektedir.

\section{KAYNAKLAR}

1. Neame RL, Carr AJ, Muir K, et al. UK community prevalence of knee chondrocalcinosis: evidence that correlation with osteoarthritis is through a shared association with osteophyte. Ann Rheum Dis. 2003; 62:513-8.

2. Shidham V, Chivukula M, Basir Z, et al. Evaluation of crystals in formalin-fixed, paraffin-embedded tissue sections for the differential diagnosis of pseudogout, gout and tumoral calcinosis. Mod Pathol. 2001; 14:806-10.

3. Macfarlane GJ, El-Metwally A, De Silva V, et al. Evidence for the efficacy of complementary and alternative medicines in the management of rheumatoid arthritis: a systematic review. Rheumatology (Oxford). 2011; 50:1672-83.

4. Tutuncu Z, Kavanaugh A. Rheumatic disease in the elderly: rheumatoid arthritis. Rheum Dis Clin North Am. 2007;33:57-70.

5. Villa-Blanco JI, Calvo-Alén J. Elderly onset rheumatoid arthritis: differential diagnosis and choice of firstline and subsequent therapy. Drugs Aging. 2009;26: 739-50.

6. Ergin ES, Kibar S. İleri yaşta artrit: romatoid artrit ve ayırıcı tanısı. Turk J Phys Med Rehab. 2013;59:242-9.

7. Yıldız B, Bodur H. Kalsiyum pirofosfat dihidrat kristal depolanma hastalı̆̆ (psödogut): olgu sunumu. Arch Rheumatol. 2006;21:34-6.

8. Tuncer T, Çay HF, Kaçar C, et al. Diz osteoartrit tedavisinde kanıta dayalı öneriler: Türkiye Romatizma Araştırma ve Savaş Derneği uzlaşı raporu. Turk J Rheumatol. 2012;27:1-17

9. Kean CO, Birmingham TB, Garland SJ, et al. Preoperative strength training for patients undergoing high tibial osteotomy: a prospective cohort study with historical controls. J Orthop Sports Phys Ther. 2011;41:52-9

10. Zeng C, Li H, Yang T, et al. Electrical stimulation for pain relief in knee osteoarthritis: systematic review and network meta-analysis. Osteoarthritis Cartilage. 2015;23:189-202.

11. O'Reilly SC, Jones A, Muir KR, et al. Quadriceps weakness in knee osteoarthritis: the effect on pain and disability. Annals Rheum Dis. 1998;57:588-94.

12. Naito Y, Yamaguchi S, Mori Y, et al. A randomized, double-blind, sham-controlled study of static electric field therapy by high voltage alternating current for active rheumatoid arthritis. J Clin Biochem Nutr. 2013;53:63.

13. Chuter VH, Janse de Jonge XA. Proximal and distal contributions to lower extremity injury: a review of the literature. Gait Posture. 2012;36:7-15.

14. Willson JD, Kernozek TW, Arndt RL, et al. Gluteal muscle activation during running in females with and without patellofemoral pain syndrome. Clin Biomech (Bristol, Avon). 2011;26:735-40.

15. Chevidikunnan MF, Al Saif A, Gaowgzeh RA, et al. Effectiveness of core muscle strengthening for improving pain and dynamic balance among female patients with patellofemoral pain syndrome. J Phys Ther Sci. 2016;28:1518-23. 